\title{
THEORETICAL FUNDAMENTALS OF INNOVATION OF HIGHER EDUCATION IN UKRAINE
}

\author{
Svitlana Atamanyuk ${ }^{1}$, Olena Semenikhina ${ }^{2}$, Inna Shyshenko ${ }^{3}$ \\ ${ }^{1}$ Candidate of Sciences in Physical Education and Sports, Associate Professor, Associate Professor of the \\ Department of Physical Culture, Olympic and Non-Olympic Sports, Zaporizhzya Polytechnic National \\ University, Zaporizhzya, Ukraine, e-mail: shiinna@ukr.net, ORCID: 0000-0002-4800-5965 \\ ${ }^{2}$ Doctor of Pedagogical Sciences, Professor, Head of the Department of Informatics, Makarenko Sumy State \\ Pedagogical University, Sumy, Ukraine, e-mail: shiinna@ukr.net, ORCID: 0000-0002-3896-8151 \\ ${ }^{3}$ Candidate of Pedagogical Sciences, Associate Professor, Associate Professor of the Department of \\ Mathematics, Makarenko Sumy State Pedagogical University, Sumy, Ukraine, e-mail: shiinna@ukr.net, \\ ORCID: 0000-0002-1026-5315
}

\begin{abstract}
Innovative education is the development and expansion of quality education, a vital way to develop the creativity, abilities and talents of high quality students. This should be a key point in the organization of higher education in Ukraine. The introduction of innovative technologies allows to conduct the educational process and develop the system of higher education at a qualitatively new level. Thus, innovative activity in the educational process is aimed at transforming existing forms and methods of teaching and education, creating new goals and means of its implementation, so it is one of the types of productive, creative activities of people. Definitions of the general context of the study of vocational training are organized into the following categories of concepts: «innovative development», «innovation», «innovation process», «innovation», «innovation», «innovation», «intellectualization», «innovation», «innovations», «innovation process». Professional training of future specialists in free economic education should be perceived as a process of forming the readiness of future specialists for professional activity and is a prerequisite for achieving their high competitiveness in the labor market, should cover not only traditional areas but also new substructures, including innovation. Scientists see the essence of the application of innovations in the implementation of new ideas, changes brought to the stage of practical use, and consider them as activities that stimulate the progressive development of the information component through semantic, structural and organizational renewal and technological modernization of all processes. Today the educational space of Ukraine is actively filled with pedagogical innovations. As a result, the higher education system faces the challenge of transitioning to active learning using innovative tools or technologies. The new paradigm of education development necessitates appropriate changes in the professional training of future specialists in higher education.
\end{abstract}

Keywords: educational space of Ukraine; pedagogical innovations; higher education; innovative education; professional training.

JEL Classification: I23, I29

Formulas: 0; fig.: 0; tabl.: 0; bibl.: 22

Introduction. Dynamic changes in the ways of generating and disseminating knowledge change the competitive environment of the national higher education system, and its traditional providers - universities, require innovative solutions, and thus determine the relevance of developing new theoretical concepts and implementing applied models of the educational environment. Innovative education is the development and expansion of quality education, a vital way to develop the creativity, abilities and talents of high quality students.

Innovation is the process by which new assets are created or new potential for action is developed. Innovation is the key to competitive advantage in a changing environment. This is an important source of market and economic growth, and hence 
all other areas of public life. In a complex and changing environment, innovation creates value and a lasting advantage, as well as helping to work better and create new products and services. In other words, innovation can be seen as the adoption of a new idea, product, method or service. In addition, innovations such as the introduction of inventions and modified products and services have commercial value and are seen as a process or sequence of events in which people interact with each other to bring new ideas to the organization. Innovative potential reflects the trend towards novelty, experimentation and the creative process that help in growth and diversification. On the other hand, it is considered a successful exploitation of new ideas. In other words, it is the process of creating new things and phenomena through the necessary technological channels and creative thinking. In order to successfully move forward, it is necessary to pay more attention to innovative projects. This should be a key point in the organization of higher education in Ukraine. The introduction of innovative technologies allows to conduct the educational process and develop the system of higher education at a qualitatively new level.

Literature Review. In the generally accepted interpretation, «innovation» translated from English «innovation» means «innovation» [2], i.e. in a broad sense, «innovation is a synonym for the successful development of a particular field of activity on the basis of various innovations» [14]. The word «innovation» comes from the Latin «innovation» - «renewal», «change».

Issues of innovative development have long been studied by scientists from different countries and reflected in the works of D. Bell, P. Drucker, G. Kleiner, V. Inozemtsev, A. Galchinsky, V. Heitz, V. Seminozhenko, O. Amosha, L. Fedulova, O. Dyba, A. Chukhno, O. Melnikova, I. Galyuk, I. Artyomova and others. Problems of innovative development are studied by many scientists of Ukraine, including V. Antonyuk, V. Bazylevych, I. Zhilyaev, Y.Zaloznova, I. Kalenyuk, O. Kuklin, E. Libanova, O. Novikova, who pay considerable attention to the human factor of innovation. activities. Scholars consider innovative development as a priority of state policy aimed at ensuring long-term economic growth. Innovative development involves the recognition of the crucial role of education and human capital in shaping the socio-economic capabilities of the state and the implementation of an innovative model of its development [19]. The «Strategy of Innovative Development of Ukraine in the context of globalization challenges» [20] states that education plays an extremely important role in meeting the needs of innovative development of the country. Higher education is not only a unifying but also a constructive link in the system of the main components of the innovation economy - «education - science production - innovation» [20].

The main tasks of modern education in ensuring the innovative development of Ukrainian society are:

- improving the quality of knowledge;

- training of highly qualified specialists capable of innovative activities;

- development and implementation of modern forms, methods and technologies of teaching;

- creating favorable conditions for research work; 
- strengthening the interaction of all industries in the creation and implementation of innovations.

As noted by O. Dyba [6], researchers of modern theories of innovative development, along with the already traditional for the modern business entity the concepts of «innovative development», «innovation», «innovation process», consider new categories - «innovation», «innovation», «innovation», «intellectualization», «innovation». Focusing only on the traditional established categories of «innovation», «innovation process» does not allow to fully outline the potential opportunities and main aspects of obtaining results from innovation.

Aims. The article aims is a theoretical substantiation of the basic concepts of the theory of innovative development of the higher education system.

Methods. Theoretical methods: systematic analysis of scientific, psychological and pedagogical, methodological literature; generalization and systematization of theoretical information on the introduction of innovative changes in the higher education system of Ukraine.

Results. In the interpretation of scientists, the concept of «innovation» means the possession of qualitatively new capabilities and abilities of man (or economic agents) to create, disseminate various types of innovations through borrowing them from any different technical, technological, organizational, social, economic, institutional and other spheres [6].

Scientists also single out the concept of «innovation» as the ability to practically implement intellectual solutions in practice in order to obtain various effects. Innovation (from the Latin innovatio - renewal, change) is an emotional and evaluative attitude to innovation, the difference in the susceptibility of subjects to innovation, new goals, experience [7]. The concept of «innovation» is broader than innovation, because it is determined by the external and internal environment of the system and provides new knowledge, methods, concepts, approaches, the formation of new connections, which accelerates the process of adapting to change. Therefore, innovation is a characteristic that reflects the qualitative level of readiness of the system, people, for innovative change, the perception of new ideas and the ability to support and implement innovations in all spheres of social activity.

According to I. Halyuk, innovation as a qualitative characteristic of innovative development can be considered in the following aspects: as a means of continuous improvement, updating on the basis of the latest advances in science and technology, which allows to prepare the system for innovation practice; as a goal that provides for the formation and stable reproduction in the system of installations, conditions of activity, focused on the constant desire for novelty. That is, this system is open to innovation, constantly updates and improves its activities, tries to increase the efficiency of all processes that take place in it, responds quickly to changes in the external environment, and responds to external changes accompanied by the necessary changes in the internal environment. Thus, the innovativeness of the system implies, firstly, the resource readiness for change, secondly, the readiness of the system to accept changes and, thirdly, the readiness to accept changes in the system of the business environment in which it operates. The key is that innovative 
development involves, first of all, the formation of conditions for support and implementation of innovations, provided by generating change through the acquisition and dissemination of new knowledge, is systemic, implemented comprehensively taking into account changes in external and internal environment, based on objective and subjective bases of innovative development [3]. As a result, innovative individuals who possess the qualities of a creative person, acquired in an innovative socio-cultural environment in the process of joint innovative activity and communication, are trained and prepared for practical activities.

A new branch of knowledge, innovation, plays a key role in ensuring the process of intellectualization. Innovation as a modern discipline of knowledge covers issues of methodology and organization of innovation. The term «innovation» was first used in the late 80's of XX century in the scientific school of prof. V. Kolosov in order to determine the direction of scientific activity on the development and development of theoretical foundations of scientific methodology and methods of forecasting the creation of innovations, as well as methods of planning, organizing innovation and implementation of innovations [7].

Innovation studies:

- patterns of development processes;

- the mechanism of innovative and controlled changes that occur as a result of rational-volitional actions, the formation of innovations, innovations;

- change management mechanism;

- overcoming resistance to innovations, human adaptation to them;

- use and dissemination of innovation flows, innovation activities, their impact on competition, on the development of society as a whole [11].

The leading principles of innovation are revealed in the works of L. Danylenko [5], V. Lazarev [10], O. Pekhota [15], G. Sirotenko [18], O. Shapran [22] etc.

L. Danylenko [5], S. Markiyan [12], V. Saguichenko [16] argue that the effective implementation of innovative activities is possible under the condition of high creativity of both teachers and students, which involves the development of creative abilities, focus on non-standard solutions of pedagogical tasks, the ability to self-realization and self-improvement.

Discussion. Today the educational space of Ukraine is actively filled with pedagogical innovations. As a result, the higher education system faces the challenge of transitioning to active learning using innovative tools or technologies. The new paradigm of education development necessitates appropriate changes in the professional training of future specialists in physical culture and sports in higher education.

In modern pedagogical science there are the following interpretations of the concept of "innovation":

- updating, changes, introduction of new [5];

- the process of creating and using innovations [1].

The introduction of such innovations changes the results of the educational process, creating improved or new: educational, didactic, educational systems; the content of education; methods, forms, means of personal development, organization 
of training and education; technologies of management of educational institutions, system. Innovative activity is a systematic type of activity aimed at implementing innovations based on the use and implementation of new scientific knowledge, ideas, approaches; transformation of known results of scientific researches and practical developments into a new or improved product [9].

Innovation is a system or element of the pedagogical system that allows to effectively solve the tasks that correspond to the progressive trends of society. Innovative learning is a process organized for the future, focused on training professionals to work in new conditions [4]. Innovative pedagogical process is a holistic educational process that reflects the unity and relationship of education and training, which characterizes the joint activities of cooperation and joint creativity of its subjects, contributing to the fullest development and self-realization of the individual [4]. The skill of a students is manifested mainly in the successful mastery of teaching methods and education, creative application of the latest advances in pedagogy and advanced pedagogical experience, rational guidance of cognitive and practical activities of students, their intellectual development. It has a complex, multifaceted nature, embodies the unity of scientific, technological, organizational measures [8].

Innovative pedagogical technologies are newly created or improved pedagogical systems that provide a high level of educational process. In other words, innovative pedagogical technology is an active scenario of organization at the modern level of the educational process of students in order to achieve a certain goal. In its specific form, pedagogical technology is a model of the system of actions of teachers and pupils or teachers and students that must be performed in the course of an optimally organized educational process in order to obtain a high level of development of subjects of learning [10].

Scientists see the essence of the application of innovations in the implementation of new ideas, changes brought to the stage of practical use, and also consider them as activities that stimulate the progressive development of the information component through semantic, structural and organizational renewal and technological modernization of all processes [17].

Researchers [13] emphasize that work in an innovative mode requires the teacher to build an educational space based on constantly changing interests and educational needs, as well as the implementation of an individual approach to each participant in the learning process.

Innovative pedagogical technology includes the technology of teaching and education, which is a means of organizing the educational process and focuses on a wide range of methods and teaching aids used in the educational process with students [9], and the fullest goal of innovation in the free economic zone is realized through raising the level of:

- information support and information support of educational and scientific processes through organizational innovations;

- technological innovations;

- quality of new information products. 
According to L. Sushchenko [21], the main task of the Free Economic Zone, which trains future specialists in physical culture and sports, should be to form a subject of professional activity capable of increasing one's professional potential, mastering knowledge of the process of physical education and social culture in the field. physical education and sports taking into account modern pedagogical technologies, predicted by innovations.

Thus, innovative activity in the educational process is aimed at transforming existing forms and methods of teaching and education, creating new goals and means of its implementation, so it is one of the types of productive, creative activities of people.

Conclusions. Thus, as a result of the analysis of the general definitions of our research we have established:

1) definitions of the general context of the study of vocational training are organized into the following categories of concepts: «innovative development», «innovation», «innovation process», «innovation», «innovation», «innovation», «intellectualization», «innovation», «innovations», «innovation process»;

2) professional training of future specialists in free economic education should be perceived as a process of forming the readiness of future specialists for professional activity and is a prerequisite for achieving their high competitiveness in the labor market, should cover not only traditional areas but also new substructures, including innovation;

3) scientists see the essence of the application of innovations in the implementation of new ideas, changes brought to the stage of practical use, and consider them as activities that stimulate the progressive development of the information component through semantic, structural and organizational renewal and technological modernization of all processes.

Author contributions. The authors contributed equally.

Disclosure statement. The authors do not have any conflict of interest.

References:

1. Abasov, Z. (2006), Ponyatiyno-terminologicheskiy aparat innovatsionnoy pedagogicheskoy deyatelnosti [Conceptual and terminological apparatus of innovative pedagogical activity], Filosofiya obrazovaniya, 1 (15), 5662. [in Russian].

2. Viktorova, L. (2002), Innovatsionnyie protsessyi v obrazovanii [Innovative processes in education], Innovatsii $v$ obrazovanii, 2, 6. [in Russian].

3. Haliuk, I. (2012), Teoretychni aspekty innovatyzatsii yak obiektyvnoho protsesu rozvytku ekonomichnykh system [Theoretical aspects of innovation as an objective process of economic systems development], Ekonomichnyi visnyk NHU, 3, 12-17. [in Ukrainian].

4. Honcharenko, S. (1997), Ukrainskyi pedahohichnyi slovnyk [Ukrainian pedagogical dictionary], Kyiv : Lybid. [in Ukrainian].

5. Danylenko, L. (2007), Menedzhment innovatsii v osviti [Innovation management in education], Kyiv : Shk. svit, 2007. [in Ukrainian].

6. Dyba, O.M. (2017), Innovatyzatsiia vyrobnytstva: teoretychni osnovy ta prykladni aspekty [Production innovation: theoretical foundations and applied aspects], Investytsii: praktyka ta dosvid, 22, 27-31. [in Ukrainian].

7. Innovatsii u vyshchii osviti: hlosarii terminiv i poniat (2015) [Innovations in higher education: a glossary of terms and concepts] / za red. I.V. Artomova; [uklad.: I.V. Artomov, A.V. Shershun, S.V. Piasetska-Ustych], Uzhhorod: PP «AUTDOR - ShARK». [in Ukrainian].

8. Kozak, L.V. Pryntsypy innovatsiinoi profesiinoi diialnosti vykladacha vyshchoi shkoly [Principles of innovative professional activity of a high school teacher], URL : e-learning.kubg.edu.ua [in Ukrainian].

9. Konokh, A., Prytula, O. (2010), Vykorystannia suchasnykh innovatsiinykh tekhnolohii v protsesi fizychnoho vykhovannia studentiv na osnovi pohlyblenoho kursu profesiino-prykladnoi fizychnoi pidhotovky [The use of modern innovative technologies in the process of physical education of students on the basis of an in-depth course of 
professional and applied physical training], Pedahohika, psykholohiia ta medyko-biolohichni problemy fizychnoho vykhovannia i sportu, 10, 49 -51. [in Ukrainian].

10. Lazarev, V.S. (2002), Sistemnoe razvitie shkolyi [Systemic development of the school]: monografiya, Moskva : Piter. [in Russian].

11. Mahuta, O.V. (2018), Innovatyzatsiia vyshchoi osvity v Ukraini na osnovi zaluchennia tsilovoho kapitalu (endavmentu) [Innovation of higher education in Ukraine on the basis of attracting target capital (endowment)], Dys.... kand.ekon. nauk za spetsialnistiu 08.00 .03 - ekonomika ta upravlinnia natsionalnym hospodarstvom (051 Ekonomika), Instytut pidhotovky kadriv derzhavnoi sluzhby zainiatosti Ukrainy Ministerstva sotsialnoi polityky Ukrainy, Kyiv. [in Ukrainian].

12. Markiian, S.V. (2006), Innovatsii yak faktor rozvytku osvity [Innovation as a factor in the development of education], Kharkiv. [in Ukrainian].

13. Moskalenko, N., Savchenko, V. (2013), Innovatsiini tekhnolohii u systemi pidvyshchennia kvalifikatsii vchyteliv fizychnoi kultury pochatkovykh klasiv [Innovative technologies in the system of advanced training of primary school physical education teachers], Fizychne vykhovannia riznykh hrup naselennia, 3, 14 - 19. [in Ukrainian].

14. Ostapchuk, O. (2003), Innovatsiini protsesy v osviti: poshuk istyny tryvaie [Innovative processes in education: the search for truth continues]. Pidruchnyk dlia dyrektora, 4, 3 - 8. [in Ukrainian].

15. Pekhota, O. M., Kiktenko, A. Z., Liubarska, O. M. (2001), Osvitni tekhnolohii [Educational technologies], Kyiv. [in Ukrainian].

16. Sahuichenko, V. (2009), Rol rehionalnykh instytutiv pisliadyplomnoi pedahohichnoi osvity u rozvytku partnerstva shkoly ta hromadskosti [The role of regional institutes of postgraduate pedagogical education in the development of school-public partnership]. Problemy zabezpechennia neperervnosti ta nastupnosti protsesu formuvannia smyslozhyttievykh tsinnostei na riznykh rivniakh vitchyznianoi systemy osvity, Dnipropetrovsk. [in Ukrainian].

17. Svistelnyk, I. (2014), Innovatsiini protsesy v informatsiinii diialnosti ZVO fizkulturnoho profiliu [Innovative processes in the information activity of ZVO of physical culture profile]. Moloda sportyvna nauka Ukrainy, 4, 132 135. [in Ukrainian].

18. Syrotenko, H.O. (2003), Shliakhy onovlennia osvity: naukovo-metodychnyi aspect [Ways to update education: scientific and methodological aspect], Kharkiv: Osnova. [in Ukrainian].

19. Sobolieva, S.M. (2012), Osvita yak stratehichnyi resurs innovatsiinoho rozvytku ukrainskoho suspilstva [Education as a strategic resource for innovative development of Ukrainian society], Zovnishnia torhivlia: pravo, ekonomika, finansy, 3, 100-106. [in Ukrainian].

20. Stratehiia innovatsiinoho rozvytku Ukrainy $v$ umovakh hlobalizatsiinykh vyklykiv [Strategy of innovative development of Ukraine in the conditions of globalization challenges]; URL: http://kno.rada.gov.ua [in Ukrainian].

21. Sushchenko, L.P. (2003), Teoretyko-metodolohichni zasady profesiinoi pidhotovky maibutnikh fakhivtsiv fizychnoho vykhovannia ta sportu $u$ vyshchykh navchalnykh zakladakh [Theoretical and methodological principles of professional training of future specialists in physical education and sports in higher educational institutions]: avtoref. dys. ... doktora ped. nauk: 13.00.04, Kyiv. [in Ukrainian].

22. Shapran, O.I., Dobroskok, I.I., Kotsur, V.P., \& Nikitchyna S.O. (2008), Innovatsiini pedahohichni tekhnolohii: teoriia ta praktyka vykorystannia u vyshchii shkoli [Innovative pedagogical technologies: theory and practice of use in higher school], Pereiaslav-Khmelnytskyi, Vydavnytstvo S.V. Karpuk. [in Ukrainian]. 